\title{
Expression and Association of SCD Gene Polymorphisms and Fatty Acid Compositions in Chicken Cross
}

\author{
A. Furqon ${ }^{a}$, A. Gunawan ${ }^{\text {, }}$, N. Ulupi ${ }^{b}$, T. Suryati ${ }^{\text {b }}$ \& C C. Sumantri ${ }^{b, c, *}$ \\ ${ }^{a}$ Graduate School of Bogor Agricultural University \\ ${ }^{b}$ Department of Animal Production and Technology, Faculty of Animal Science, Bogor Agricultural University \\ Jalan Agatis, Darmaga Campus, Bogor 16680, Indonesia \\ cResearch Center for Bioresources and Biotechnology, Bogor Agricultural University \\ Jalan Kamper, Darmaga Campus, Bogor 16680, Indonesia \\ (Received 05-10-2017; Reviewed 15-11-2017; Accepted 27-11-2017)
}

\begin{abstract}
Stearoyl-CoA desaturase (SCD) is an integral membrane protein of endoplasmic reticulum (ER) that catalyzes the rate limiting step in the monounsaturated fatty acids from saturated fatty acids. Selection for fatty acids traits based on molecular marker assisted selection is needed to increase a value of chicken meat. This study was designed to analyze expression and associations of SCD gene polymorphisms with fatty acid traits in F2 kampung-broiler chicken cross. A total of 62 F2 kampungbroiler chicken cross ( 29 males and 33 females) were used in this study. Fatty acid traits were measured at 26 weeks of age. Samples were divided into two groups based on fatty acid traits (the highest and the lowest). Primers in exon 2 region were designed from the genomic chicken sequence. The SNP g.37284A $>\mathrm{G}$ was detected and polymerase chain reaction-restriction fragment length polymorphism (PCR-RFLP) method was then used to genotype. The expression of SCD gene was analyzed using quantitative real time PCR (qRT-PCR). The result showed that there were three genotypes (AA, AG, and GG) found in this study. The SCD $\mid$ AciI polymorphism was significantly associated with palmitoleic acid (C16:1), fatty acids total and saturated fatty acid in 26 weeks old of F2 kampungbroiler chicken cross $(\mathrm{P}<0.05)$. The SCD gene was expressed for polyunsaturated fatty acids in liver tissue in two groups of chickens. In conclusion, the SCD gene could be a candidate gene that affects fatty acids traits in F2 kampung-broiler chicken cross.
\end{abstract}

Keywords: kampung-broiler chicken cross, fatty acid, SCD gene, polymorphism, expression

\section{ABSTRAK}

Stearoyl-CoA desaturase (SCD) merupakan sebuah protein membran pada retikulum endoplasma (RE) yang mengkatalis tahap laju pembatasan asam lemak tak jenuh tunggal dari asam lemak jenuh. Program seleksi untuk asam lemak yang didasarkan dengan penanda molekuler dibutuhkan untuk meningkatkan nilai dari daging ayam. Penelitian ini didesain untuk menganalisis ekspresi gen SCD dan asosiasinya dengan sifat asam lemak pada ayam silangan kampung-broiler G2. Sebanyak 62 ekor ayam silangan kampung-broiler ( 29 jantan dan 33 betina) digunakan dalam penelitian ini. Sifat asam lemak diukur pada umur 26 minggu. Sampel dibagi kedalam dua grup berdasarkan sifat asam lemaknya (tertinggi dan terendah). Primer pada daerah exon 2 didesain berdasarkan runutan basa genom ayam. Sebuah SNP g.37284A>G dideteksi dan kemudian metode polymerase chain reaction-restriction fragment length polymorphism (PCR-RFLP) digunakan untuk menentukan genotipe. Ekspresi gen SCD dianalisis menggunakan kuantitatif real time PCR. Hasil menunjukkan bahwa terdapat tiga genotipe (AA, AG, dan GG) yang ditemukan pada penelitian ini. Keragaman SCD $\mid$ AciI berasosiasi dengan asam lemak palmitoleat (C16:1), total asam lemak dan asam lemak jenuh pada ayam silangan kampung-broiler G2 $(P<0.05)$. Gen SCD juga terekspresi untuk sifat asam lemak tak jenuh ganda pada organ hati di kedua grup ayam. Dapat disimpulkan bahwa gene SCD dapat dijadikan kandidat gen yang mempengaruhi sifat asam lemak pada ayam silangan kampung-broiler G2.

Kata kunci: ayam silangan kampung-broiler, asam lemak, gen SCD, keragaman, ekspresi

${ }^{*}$ Corresponding author:

E-mail: csumantri12@gmail.com 


\section{INTRODUCTION}

Indonesian native chickens are important genetic resources, particularly for growth, meat and egg production. Commonly, Indonesian native chickens are raised using traditional production techniques but have a good adaptation to the tropical climate in Indonesia (Abubakar et al., 2014). They are not considered as the main source of family income and just as a side-line activity. The productivity of Indonesian native chicken is still low (Sulandari et al., 2007) but can be increased with better management and genetic improvement. In the other hand, Indonesian native chickens supply meat that has specific texture and taste. It contains lower fat and are preferred by consumers. As a result, native chicken meat is more expensive than broiler meat. There is a high potential for genetic improvement of indigenous chickens due to large genetic variation in production and meat quality traits. Crossbreeding program with broiler can be done to improve the genetic productivity of Indonesian native chicken.

Identifying candidate genes related to meat quality traits will provide an opportunity for genetic improvement in breeding programs, especially in fatty acids traits. These traits affect not only taste and texture in meat but also healthy status for the human. The study of molecular genetics and genomic technologies have led to the improvement of meat quality of farm animals (Gao et al., 2007). An expression study and a polymorphic locus associated with fatty acids traits can be used as genetic markers. The genetic markers can be used for genetic improvement in the breeding program. (Ghanem et al., 2016)

Stearoyl-CoA desaturase (SCD) is an intrinsic membrane protein that binds to the endoplasmic reticulum (ER) and catalyzes the rate limiting step in the monounsaturated fatty acids from saturated fatty acids (Heinemann \& Ozols, 2003). There are 5 variants of SCD called SCD1, SCD2, SCD3, SCD4 and SCD5 in different organisms (Paton \& Ntambi, 2009; Flowers \& Ntambi, 2008; Castro et al., 2011). The SCD gene is encoding an enzyme that catalyzes delta $(\Delta) 9$ desaturation of SFA and MUFA (Ohsaki et al., 2009). The SCD gene encoded delta $(\Delta) 9$ desaturation to produce palmitoleic acid (C16:1) and oleic acid (C18:1), both of C16:1 and C18:1 fatty acid diversely expressed in the physiological process (Wu et al., 2013; Alexander et al., 2007).

Resnyk et al. (2013) reported that SCD gene was expressed in abdominal fat in fat and lean chicken. In the chicken, SCD gene expression is regulated by leptin, cerulenin, nutritional state, and gender in a tissue-specific manner (Dridi et al., 2007). In another study, SCD gene expression was affected by age (Bohannon-Stewart et al., 2014). In mammals, the expression of SCD gene was analyzed and associated with fatness and fatty acids (Maharani et al. 2013b; Oh et al., 2013; Lim et al., 2015)

The objectives of this study were to analyze an expression of SCD gene using RT-PCR, identify a polymorphism of SCD gene exon2 using PCR-RFLP and evaluate associations between a polymorphism of SCD gene and fatty acids compositions on F2 kampungbroiler chicken cross.

\section{MATERIAL AND METHODS}

\section{Experimental Populations and Management}

A total of 29 males and 33 females Indonesian kampung-broiler chicken cross at 26 weeks of age were used in the current study. The blood ratio of Indonesian kampung-broiler chicken cross (F2) was 25\% kampung, $50 \%$ kampung-broiler and 25\% broiler (strain Cobb). The samples were divided into two groups (the highest and the lowest) according fatty acids traits for gene expression study. All chickens had access to feed and water ad libitum. From hatch to 8 week of age, chickens received a starter feed $(4,080 \mathrm{kcal}$ of gross energy $/ \mathrm{kg}$ and $19,03 \%$ of crude protein) and from 9 to 24 weeks of age, chickens were fed a grower diet $(4,001 \mathrm{kcal}$ of gross energy $/ \mathrm{kg}$ and $17,42 \%$ of crude protein).

\section{Phenotypic Measurements}

Fatty acids traits were analyzed at 26 weeks of age. A part of leg chicken was used for fatty acids analysis. Fatty acids analysis was done according to Association of Official Analytical Chemists (AOAC, 2012). These measurements included fat content (FC), saturated fatty acids (SFA), monounsaturated fatty acids (MUFA), polyunsaturated fatty acids (PUFA), and total fatty acids (TFA) .

\section{RNA Isolation and qRT-PCR}

The liver of chickens ( $n=3$ per group) was extracted with JET RNA Purification Kit (Thermo Scientific, Lithuania, EU) and then stored at $-20^{\circ} \mathrm{C}$ temperature. In this study, RNA was transcripted into complementary DNA (cDNA) using Transcriptor Synthesis First Strand cDNA Kit (Thermo Scientific, Lithuania, EU). RNA concentrations were measured with a NanoDrop spectrophotometer (NanoDrop Spectophotometers 2000, Thermo Scientific, USA). PCR primers were designed in MEGA 5.0 and checked the profile using Primer Stat (SCD Forward: 5'-GGT GAC CAA GAA TGG GAA TG'3, SCD reverse: 5'-CCA ATA ATG GCC CCT AGA TG'3, GAPDH forward: 5'-GTG TTG TGG ACT TGA TGG TC-`3, GAPDH reverse: 5’-GAC AGA AGG GAA CAG AAC TG-'3). The length of mRNA product of SCD and GAPDH genes were 192 and 160 bp respectively. All RTqPCR assays were conducted using SYBR Green Select Master Kit (Applied biosystem, USA). The reaction was done in $10 \mu \mathrm{L}$ containing $50 \mathrm{ng}$ of total RNA and $0.4 \mu \mathrm{M}$ of each primer. Thermal cycles contained one cycle of pre-incubation at $95^{\circ} \mathrm{C}$ for $5 \mathrm{~min}, 35$ cycles of amplification $\left(95^{\circ} \mathrm{C}\right.$ for $10 \mathrm{~s}$ and $60^{\circ} \mathrm{C}$ for $\left.20 \mathrm{~s}\right)$. Data of qRT-PCR were analyzed using 2[delta-delta] CT method (Schmittgen \& Livak, 2008).

\section{DNA Isolation and PCR Amplification}

Blood samples were collected from Vena axillaris. Genomic DNA was isolated according to Sambrook et al., (1989). The PCR primers of SCD gene exon 2 used in this study are based on a previously study (Maharani 
et al., 2013). These primers (5' CCC CCA GAA AGA AAA AGT CC 3' and 5' CAA AAA TCC CAC CCA ACA AC 3)' were designed to amplify a 468-bp fragment by primer stat according to the chicken genomic sequence in the GenBank database (accession number NC_006093). The PCR reaction conditions were $94^{\circ} \mathrm{C}$ for $5 \mathrm{~min}, 35 \mathrm{cycles}$ of $94^{\circ} \mathrm{C}$ for $10 \mathrm{~s}, 60^{\circ} \mathrm{C}$ for $20 \mathrm{~s}, 72^{\circ} \mathrm{C}$ for $30 \mathrm{~s}$, and an extension at $72^{\circ} \mathrm{C}$ for $5 \mathrm{~min}$. The $25-\mu \mathrm{L}$ reaction volume included $50 \mathrm{ng}$ of DNA template, $1 \times$ reaction buffer, 5 pmol of each primer, $0.16 \mathrm{mM}$ of deoxyribonucleotide triphosphate, $1.5 \mathrm{mM}$ of $\mathrm{MgCl}_{2}$, and 1 $\mathrm{U}$ of Taq polymerase.

\section{Screening of the Population for Restriction Enzyme- Detectable SNP}

A single nucleotide polymorphism (SNP) of the SCD gene was detected by digesting $7 \mu \mathrm{L}$ of the 468 bp PCR product with $3 \mathrm{U}$ of the AciI enzyme (Thermo Fisher Scientific Inc.) at $37^{\circ} \mathrm{C}$ overnight. The restriction digests were electrophoresed for $45 \mathrm{~min}$ at 100 $\mathrm{V}$ on a $2.0 \%$ agarose gel with ethidium bromide. Individual PCR-RFLP fragment sizes for the gene were determined by visualizing the band pattern under UV Transilluminator (AlphaImager ${ }^{\circledR} \mathrm{EP}$ ).

\section{Statistical Analysis}

Genotype and allele frequencies. The genotype and allele frequencies were analyzed using genotyping data based on the populations of kampong chicken (Nei \& Kumar, 2000). Genotype frequency was calculated by the following formula:

$$
\mathrm{X}_{\mathrm{ii}}=\mathrm{n}_{\mathrm{ii}} / \mathrm{N}
$$

Allele frequency was calculated by the following formula:

$$
\mathrm{Xi}=\left(2 \mathrm{n}_{\mathrm{ii}}+\sum \mathrm{n}_{\mathrm{ij}}\right) / 2 \mathrm{~N}
$$

Description:

$\mathrm{X}_{\mathrm{ii}}=\mathrm{ii}_{\text {th }}$ genotype frequency

$X_{i}=i_{\text {th }}$ allele frequency

$n_{\mathrm{ii}}=$ Number of the sample of ii genotype

$n_{\mathrm{ij}}=$ Number of the sample of ij genotype

$\mathrm{N}=$ Total samples

Association study. The association between the polymorphism and body composition traits was analyzed using the GLM procedure (SAS Inst. Inc., Cary, NC). The model was fitted with the genotype $(G ; 3$ levels; AA, AG, GG) as random effects, as follows:

$$
Y=\mu+G+S+e \text {, }
$$

Where $Y$ is the dependent variable for trait measured in the population, $\mu$ is the overall population mean for traits, $G$ is the genotype effects, $S$ is sex effects and $e$ is the random error. Significant differences between means of the different genotypes were calculated using the Duncan test. Significance was determined as $\mathrm{P}<0.05$, unless otherwise specified.

\section{RESULTS}

\section{An Expression Study of SCD Gene}

In this study, mRNA expression analyzed by qRTPCR demonstrated that the SCD gene was expressed in liver tissue. There were five fatty acid traits analyzed for gene expression (Figure 1). The chickens were divided into two groups for each trait (the highest and the lowest level). According to relative expression between SCD and GAPDH gene (housekeeping gene), there were no different expression between the highest and lowest group on fat content, total fatty acid, saturated fatty acids and monounsaturated fatty acids. There was the only different expression on polysaturated fatty acids between the highest and lowest group in the kampungbroiler chicken cross.

\section{A Polymorphism Study of SCD Gene}

The $468 \mathrm{bp}$ fragment of second exon of SCD gene was succesfully amplified and shown in Figure 2. Three genotypes were detected and defined as AA, AG and GG. The 468 bp fragment was succesfully digested with Aci I restriction enzyme. The digested PCR products had fragment sizes of 236, 141 and $91 \mathrm{bp}$ for the GG genotype, $327 \mathrm{bp}$ and $91 \mathrm{bp}$ for the AA genotype, and a combination of 327, 236, 141 and 91 bp for AG genotype. According to SCDIAciI locus polymorphism in F2 kampung-broiler chicken cross, the genotype frequency of AA, AG and GG were 0.306, 0.484, and 0.210 respectively. The alelle frequency of A and G were 0.548 and 0.452 respectively.

\section{An Association Study of SCD Gene Polymorphism and Fatty Acids Traits}

The association of SCD gene polymorphism and fatty acid traits in 26 weeks old kampung-broiler chicken cross was summarized in the Table 1 . The g.37284A $>$ G SNP of SCD gene was generally significantly associated with fatty acids composition in 26 weeks old chicken. There were significant associations between the SCD polymorphism and fatty acids C16:1 (palmitoleic acids), total fatty acids, and saturated fatty acids in 26 weeks old chicken. No significant difference was observed in fat content, monosaturated fatty acids (MUFA) and polyunsaturated fatty acids (PUFA) .

\section{DISCUSSION}

In expression study, the SCD gene was successfully expressed in liver tissue in F2 kampung-broiler chicken cross. According to relative expression, there were no the different expression on fat content, total fatty acid, saturated fatty acids and monounsaturated fatty acids. There was only the different expression on polysaturated fatty acids in liver tissue. This result indicated that SCD gene expression affected polysaturated fatty acids (PUFA) on final product of the fatty acid conversion in liver tissue of chicken. In another study, the expression profile of SCD gene in liver was different in response 

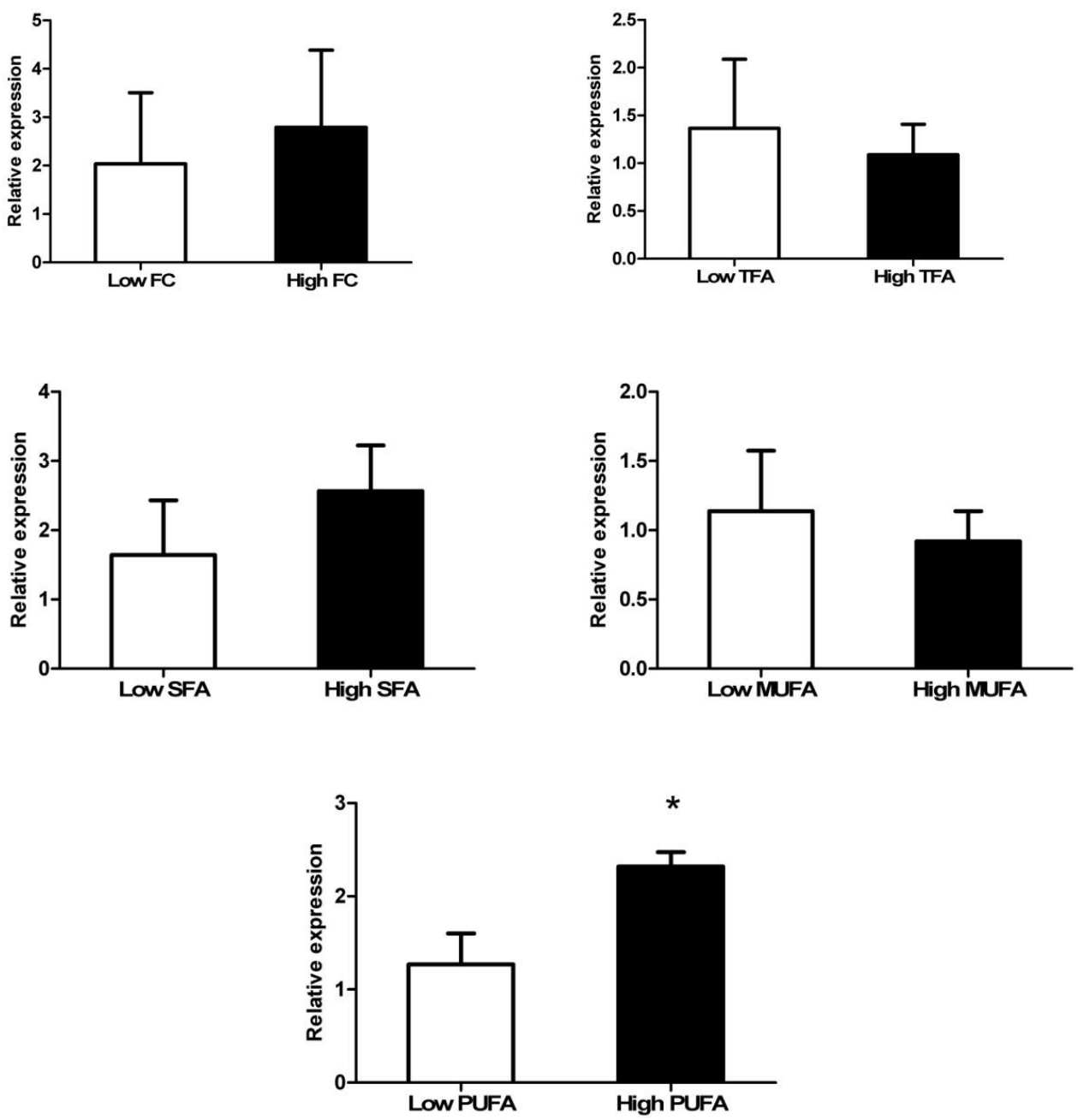

Figure 1. SCD mRNA Expression in liver tissue from group 1 and group 2 by qRT-PCR
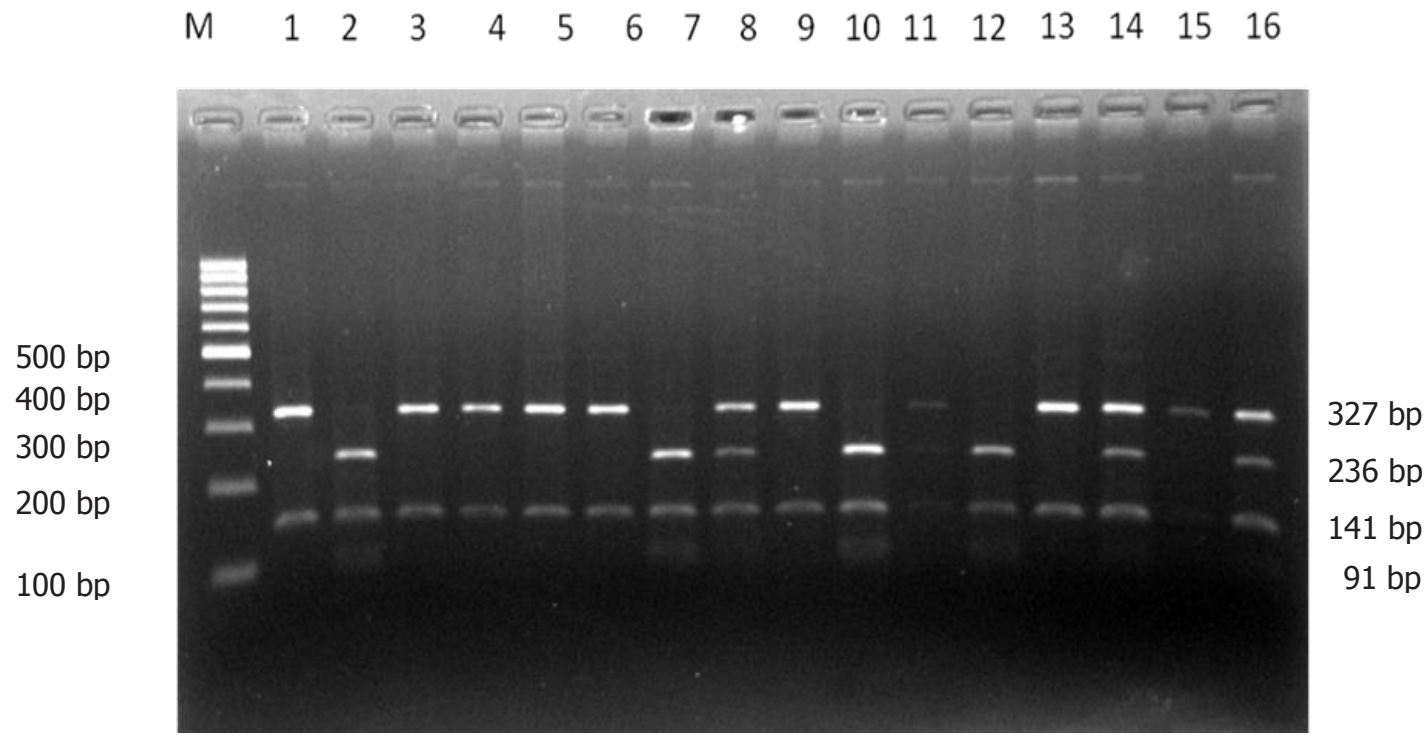

Figure 2. The PCR-RFLP pattern for SCD gene exon 2 region with AciI restriction enzyme. M=100bp markers; 1,3-6,9,13,15= AA genotype; 2,7,10,12= GG genotype; 8,11,14,16= AG genotype. 
Table 1. Fatty acids composition of Indonesian Kampung-broiler chicken cross at different genotypes (Means \pm SD)

\begin{tabular}{|c|c|c|c|}
\hline \multirow{2}{*}{$\begin{array}{l}\text { Fatty acids } \\
\text { composition }^{3}\end{array}$} & \multicolumn{3}{|c|}{ Genotype } \\
\hline & $\mathrm{AA}(\mathrm{n}=19)$ & $\mathrm{AG}(\mathrm{n}=30)$ & GG(n=13) \\
\hline Fat content & $4.85 \pm 1.42$ & $4.47 \pm 1.64$ & $4.58 \pm 1.66$ \\
\hline $\mathrm{C} 12$ & $0.05 \pm 0.01$ & $0.04 \pm 0.01$ & $0.05 \pm 0.02$ \\
\hline C14 & $0.57 \pm 0.04$ & $0.53 \pm 0.05$ & $0.54 \pm 0.04$ \\
\hline C14:1 & $0.07 \pm 0.03$ & $0.08 \pm 0.04$ & $0.08 \pm 0.02$ \\
\hline C15 & $0.11 \pm 0.08$ & $0.09 \pm 0.01$ & $0.08 \pm 0.01$ \\
\hline $\mathrm{C} 16$ & $20.56 \pm 1.35$ & $19.06 \pm 1.47$ & $19.70 \pm 1.78$ \\
\hline C16:1 & $2.32 \pm 0.82^{\mathrm{b}}$ & $2.44 \pm 0.69^{\mathrm{ab}}$ & $2.69 \pm 0.80^{a}$ \\
\hline $\mathrm{C} 17$ & $0.17 \pm 0.03$ & $0.17 \pm 0.03$ & $0.17 \pm 0.02$ \\
\hline C18 & $5.63 \pm 0.74$ & $5.06 \pm 0.70$ & $5.17 \pm 0.64$ \\
\hline $\mathrm{C} 18: \ln 9 \mathrm{t}$ & $0.16 \pm 0.03$ & $0.14 \pm 0.03$ & $0.14 \pm 0.03$ \\
\hline $\mathrm{C} 18: \ln 9 \mathrm{c}$ & $31.78 \pm 1.86$ & $31.05 \pm 2.01$ & $31.23 \pm 2.16$ \\
\hline $\mathrm{C} 18: 2 \mathrm{n} 6 \mathrm{c}$ & $20.78 \pm 2.03$ & $20.77 \pm 1.61$ & $20.16 \pm 1.79$ \\
\hline C20 & $0.16 \pm 0.03$ & $0.17 \pm 0.04$ & $0.16 \pm 0.03$ \\
\hline C18:3n6 & $0.10 \pm 0.02$ & $0.10 \pm 0.02$ & $0.09 \pm 0.01$ \\
\hline C20:2 & $0.16 \pm 0.03$ & $0.17 \pm 0.03$ & $0.15 \pm 0.02$ \\
\hline $\mathrm{C} 22$ & $0.05 \pm 0.02$ & $0.06 \pm 0.03$ & $0.06 \pm 0.01$ \\
\hline C20:4n6 & $0.68 \pm 0.28$ & $0.71 \pm 0.29$ & $0.69 \pm 0.19$ \\
\hline $\mathrm{C} 22: 6 \mathrm{n} 3$ & $0.06 \pm 0.02$ & $0.07 \pm 0.03$ & $0.07 \pm 0.03$ \\
\hline Fatty acid total & $83.44 \pm 3.68^{a}$ & $80.74 \pm 4.25^{\mathrm{b}}$ & $81.28 \pm 5.17^{b}$ \\
\hline Saturated fatty acid & $21.66 \pm 1.37^{a}$ & $20.11 \pm 1.48^{\mathrm{b}}$ & $20.76 \pm 1.81^{b}$ \\
\hline MUFA $^{1}$ & $34.34 \pm 2.50$ & $33.71 \pm 2.49$ & $34.15 \pm 2.75$ \\
\hline PUFA $^{2}$ & $21.78 \pm 2.12$ & $21.81 \pm 1.70$ & $21.16 \pm 1.84$ \\
\hline
\end{tabular}

Note:

Means in the same row with different superscripts differ significantly $(\mathrm{P}<0.05)$.

${ }^{1}$ MUFA = monounsaturated fatty acids, PUFA = polyunsaturated fatty acids; ${ }^{2}$ Numbers shown in parentheses are the number of individuals with the specified genotype; ${ }^{3}$ All of fatty acids compositions are in percent.

to fasting in chickens (Desert et al., 2008). The identified SNP confirmed in exon might play important role in transcription process (Gunawan et al., 2011). A polymorphism in the coding region directly affected the gene expression through changing the nucleotide sequence and structure of the gene and probably leading to change in mRNA synthesis, maturation, degradation, transportation, splicing or translation (Iida \& Akashi, 2000).

In polymorphism study, SCD gene fragment were successfully amplified using PCR for all samples. There was a A/G SNP at base 37284 (accession number NC_006093). The PCR-RFLP method was used successfully for genotyping the SNP in exon 2 of the SCD gene. The genotype and allele frequencies were calculated in crossbred chicken (Table 2). There were three genotypes (AA, AG, and GG) and two alleles (A and G) found in this population. The AG genotype was the highest genotype frequency in crossbred chicken. The A allele was more frequent than $G$ allele in two groups of the kampung-broiler chicken cross. This was different with the results of Maharani et al., (2013a) in the broiler. In the previous study, the genotype frequency of GG was the highest.

In the association study, there were associations between SCDIAcil locus polymorphism and fatty acid traits (palmitic acids, total fatty acids, and saturated fatty acid). The homozygous GG was significantly higher than the homozygous AA and heterozygous AG in palmitoleic acid (C16:1). The effect of this SNP indicated the increase palmitoleic acid in the homozygous GG. In fatty acids total and saturated fatty acids, the homozygous AA was significantly higher than the homozygous GG and heterozygous AG. This result indicated that homozygous AA could be a candidate marker related saturated fatty acid. In mammals, three SNPs of SCD gene in 3'UTR were associated with fat deposition and fatty

Table 2. Genotype and allele frequencies of SCD gene g.37284A>G SNP in kampung-broiler chicken cross (F2)

\begin{tabular}{|c|c|c|c|c|c|c|}
\hline \multirow{2}{*}{ Population } & \multirow{2}{*}{$\mathrm{N}$} & \multicolumn{3}{|c|}{ Genotype Frequency } & \multicolumn{2}{|c|}{ Allele Frequency } \\
\hline & & AA & AG & GG & A & G \\
\hline $\begin{array}{l}26 \text { week old in kampung-broiler } \\
\text { chicken cross (F2) }\end{array}$ & 62 & 0.306 & 0.484 & 0.21 & 0.548 & 0.452 \\
\hline
\end{tabular}


acids compositions in cattle (Jiang et al. 2008). Maharani et al. (2013b) reported that the SNPs of SCD gene were associated with fatty acids compositions in pig.

In this study, the result was similar with Maharani et al. (2013a) for palmitoleic acids. Maharani et al. (2013a) reported that SCDIAciI polymorphism associated with palmitic acid (C16), palmitoleic acid (C16:1), and saturated fatty acids. In the previous study, The GG genotype was the highest on palmitoleic acid (C16:1) and AG genotype was the highest on palmitic acid (C16) and saturated fatty acids. Palmitoleic acid had a positive effect to reduce not only bad cholesterols (Nestel et al., 1994) but also fat deposition in blood vessels and blood clot formation (Grundy, 1994). In many studies, the increasing of unsaturated fatty acids could improve flavor of meat and health benefits (Erkkila et al., 2008; Webb \& O’Neill, 2008; Zhang et al., 2008).

\section{CONCLUSION}

There was the different expression of SCD gene in liver tissue of crossbred chicken for polyunsaturated fatty acids (PUFA). There were three genotypes (AA, $A G$, and $G G)$ found in this study. The SCD gene polymorphism exon 2 was significantly associated with palmitoleic acid (C16:1), total fatty acid and PUFA in 26 weeks old crossbred chicken. The SNP can be used as a potential marker to enhance the genetic improvement for the breeding program of chicken.

\section{ACKNOWLEDGEMENT}

The authors gratefully acknowledge the member of Animal Breeding and Genetic Community of Animal Production and Technology in Bogor Agricultural University for breeding the chickens on the farm. This research was supported by Ministry of Education and Culture No. 081/SP2H/PL/Dit.Litabmas/VI/2014 (PMDSU Project 2014).

\section{REFERENCES}

Abubakar, E. Supriyatna, \& Sutopo. 2014. Genotype distribution of local chicken crosbred in poultry breeding center Temanggung-Central Java. IRJES., 3:01-14.

Alexander, L.J., M.D. MacNeil, T.W. Geary, W.M. Snelling, D. C. Rule, \& J.A. Scanga. 2007. Quantitative trait loci with additive effects on palatability and fatty acid composition of meat in a Wagyu-Limousin F2 population. Anim. Genet. 38: 506-513. https://doi.org/10.1111/j.1365-2052.2007.01643.x

AOAC. 2012. Official Methods of Analysis. 19th Ed. Association of Official Analytical Chemists, Washington, Arlington, USA.

Bohannon-Stewart, A., G. Kelley, B. Kimathi, S.H.K.V. Subramanya, J. Donkor, C. Darris, J. Tyus, A. Payne, S. Byers, D. Hui, S. Nahashon, F.C. Chen, M. Ivy, \& X. Wang. 2014. Expression of potential regulatory gene in abdominal adipose tissue of broiler chickens during early development. Genet Res Int. 2014:1-10. https://doi. org/10.1155/2014/318304

Paton, C.M. \& J.M. Ntambi. 2009. Biochemical and physiological function of stearoyl-CoA desaturase. Am. J. Physiol. Endocrinol. Metab. 297:38-37. https://doi.org/10.1152/ ajpendo.90897.2008
Castro, L.F.C, J.M. Wilson. O. Goncalves, S. Galante-Oliveira, E. Rocha, \& I. Cunha. 2011. The evolutionary history of the stearoyl-CoA desaturase gene family in vertebrates. BMC Evol. Biol. 11:132. https://doi.org/10.1186/1471-2148-11-132

Desert, C., M.J. Duclos, P. Blavy, F. Lecerf, F. Moreews, C. Klopp, M. Aubry, F. Herault, P.L. Roy, C. Berri, M. Douaire, C. Diot, \& S. Lagarrigue. 2008. Transcriptome profiling of the feeding-to-fasting transition in chicken liver. BMC Genomics, 9:611. https://doi.org/10.1186/1471-2164-9-611

Dridi, S., M. Taouis, A. Gertler, E. Decuypere, \& J. Buyse. 2007. The regulation of stearoyl-CoA desaturase gene expression in tissue specific in chickens. J. Endocrin. 192: 229-236. https://doi.org/10.1677/JOE-06-0070

Erkkilä, A., V.D.F. de Mello, U. Riserius, \& D.E. Laaksonen. 2008. Dietary fatty acid and cardiovascular disease: An epidemiological approach. Prog. Lipid Res. 47:172-187. https://doi.org/10.1016/j.plipres.2008.01.004

Flowers, M.T \& J.M. Ntambi. 2008. Role of stearoyl-coenzymeA desaturase in regulating lipid metabolism. Curr. Opin. Lipidol. 19:248-256. https://doi.org/10.1097/ MOL.0b013e3282f9b54d

Gao, Y., R. Zhang, X. Hu, \& N. Li. 2007. Application of genomic technologies to the improvement of meat quality of farm animals. Meat. Sci. 77: 36-45. https://doi.org/10.1016/j. meatsci.2007.03.026

Ghanem, H.M., A.I. Ateya, Y.Y. El Seady, S.M. Nasr, \& N.A. El Kholy. 2016. Effect of breed, apoVLDL-II gene polymorphism, and metabolic biochemical markers on growth and body composition traits in commercial broiler breeds. Asian J Anim Vet Adv., 11: 548-555. https://doi.org/10.3923/ ajava.2016.548.555

Grundy, S.M. 1994. Influence of stearic acid on cholesterol metabolism relative to other long-chain fatty acids. Am. J. Clin. Nutr. 60:986S-900S.

Gunawan, A. , K. Kaewmala, M.J. Uddin, M.U. Cinar, D. Tesfaye, C. Phatsara, E. Tholen, C. Looft, \& K. Schellander. 2011. Association study and expression analysis of porcine ESR1 as a candidat gene for boar fertility and sperm quality. Anim Repro Sci. 128.11-21.

Heinemann, F.S. \& J. Ozols. 2003. Stearoyl-CoA desaturase, a short lived protein of endoplasmic reticulum with multiple control mechanism. Prostaglandins Leukot. Essent. Fatty Acid. 68:122-133. https://doi.org/10.1016/ S0952-3278(02)00262-4

Iida, K. \& H. Akashi. 2000. A test of translational selection at 'silent' sites in the human genome: base composition comparisons in alternatively spliced genes. Gene 261: 93-102. https://doi.org/10.1016/S0378-1119(00)00482-0

Jiang, Z., J.J. Michal, D.J. Tobey, T.F. Daniels, D.C. Rule, \& M.D. MacNeil. 2008. Significant associations of stearoylCoA desaturase (SCD1) gene with fat deposition and composition in skeletal muscle. Int. J. Biol. Sci. 4:345-351. https://doi.org/10.7150/ijbs.4.345

Lim, K.S., J.M. Kim, E.A. Lee, J.H. Choe, \& K.C. Hong. 2013. A Candidate Single Nucleotide Polymorphism in the $3^{\prime}$ Untranslated Region of Stearoyl-CoA Desaturase Gene for Fatness Quality and the Gene Expression in Berkshire Pigs. Asian-Australas J Anim Sci. 28:151-157. https://doi. org/10.5713/ajas.14.0529

Maharani, D., D.W. Seo, N.R. Choi, S. Jin, M. Cahyadi, C. Jo, \& J.H. Lee. 2013a. Association of FASN and SCD genes with fatty acid composition in broilers. CNU J. Agr. Sci. 40:215220. https://doi.org/10.7744/cnujas.2013.40.3.215

Maharani, D., H. B. Park, J. B. Lee, C. K. Yoo, H. T. Lim, S. H. Han, S. S. Lee, M. S. Ko, I. C. Cho, \& J. H. Lee. 2013b. Association of the gene encoding stearoyl-CoA desaturase (SCD) with fatty acid composition in an intercross population between Landrace and Korean native pigs. Mol. Biol. Rep. 40:73-80. https://doi.org/10.1007/s11033-012-2014-0 
Nei, M. \& S. Kumar. 2000. Moleculear Evolution and Phylogenetics. New York: Oxford University Press.

Nestel, P, P. Clifton, \& M. Noakes. 1994. Effects of increasing dietary palmitoleic acid compared with palmitic and oleic acids on plasma lipids of hypercholesterolemic men. J. Lipid Res. 35:656-662.

Oh, D.Y., M.H. Jin, Y.S. Lee, J.J. Ha, B.Y. Kim, J.S. Yeo, \& J.Y. Lee. 2013. Identification of Stearoyl-CoA Desaturase (SCD) Gene Interactions in Korean Native Cattle Based on the Multifactor-dimensionality Reduction Method. Asian-Australas. J. Anim. Sci. 26: 1218-1228. https://doi. org/10.5713/ajas.2013.13058

Ohsaki H., A. Thnaka, S. Hoashi, S. Sasazaki, K. Oyama, M. Taniguchi, F. Mukai, \& H. Mannen. 2009. Effect of SCD and SREBP genotypes on fatty acid composition in adipose tissue of Japanese Black cattle herds. Anim Sci J. 80:225232. https://doi.org/10.1111/j.1740-0929.2009.00638.x

Resnyk, C.W., W. Carre, Z. Wang, T.E. Porter, J. Simon, E.L.B. Duval, M.J. Duclos, S.E. Aggrey, \& L.A. Cogburn. 2013. Transcriptional analysis of abdominal fat in genetically fat and lean chickens reveals adipokenesis, lipogenic genes and a link between hemostasis and leannes. BMC Genomics, 14:557.https://doi.org/10.1186/1471-2164-14-557
Sambrook, J., E.F. Fritschi, \& T. Maniatis. 1989. Molecular cloning: a laboratorymanual. Cold Spring Harbor Laboratory Press, New York.

Schmittgen, T.D. \& K.J. Livak. 2008. Analyzing realtime PCR data by the comparative CT method. Nat. Protoc., 3:11011108. https://doi.org/10.1038/nprot.2008.73

Sulandari, S. M.S.A. Zein, S. Paryanti \& T. Sartika. 2007. Taksonomi dan Asal Usul Ayam Domestikasi. Keanekaragaman Sumber Daya Hayati Ayam Lokal Indonesia Manfaat dan Potensi. Pusat Penelitian Ekologi, Lembaga Ilmu Pengetahuan Indonesia, Bogor. Pp: 5-23.

Webb, E.C., \& H.A. O'Neil. 2008. The animal fat paradox and meat quality. Meat Sci. 80:28-36.

Zhang, S., T. J. Knight, J. M. Reecy, \& D. C. Beitz. 2008. DNA polymorphisms in bovine fatty acid synthase are associated with beef fatty acid composition. Anim. Genet. 39:6270. https://doi.org/10.1016/j.meatsci.2008.05.029

Wu, X., X. Zhou, Q. Chang, Y. Zhang, Y. Li, L. Zhang, J. Huang, \& B. Liang. 2013. The evolutionary pattern and the regulation of stearoyl-CoA desaturase genes. BioMed Res. Int. 2013: 1-12. https://doi.org/10.1155/2013/856521 